\title{
PARTNER SELECTION IN EMERGING AND DEVELOPED MARKET CONTEXTS: RESOURCE-BASED AND ORGANIZATIONAL LEARNING PERSPECTIVES
}

\author{
MICHAEL A. HITT \\ M. TINA DACIN \\ Texas A\&M University \\ EDWARD LEVITAS \\ University of Wisconsin-Milwaukee \\ JEAN-LUC ARREGLE \\ EDHEC \\ ANCA BORZA \\ University of Babes-Bolyai
}

\begin{abstract}
This study of the international partner selection of firms from emerging (Mexico, Poland, and Romania) and developed (Canada, France, and the United States) markets supports resource-based and organizational learning explanations of such partner selection, a critical factor for success with international strategic alliances. Emerging market firms emphasized financial assets, technical capabilities, intangible assets, and willingness to share expertise in selection of partners more than developed market firms. In contrast, developed market firms tried to leverage their resources through partner selection. In particular, they emphasized unique competencies and local market knowledge and access in their partner selection more than emerging market firms.
\end{abstract}

Strategic alliances have become a highly popular strategy for entry into international markets (Lane \& Beamish, 1990; Osborn \& Hagedoorn, 1997). Alliances are designed to allow partners to share risk and resources, gain knowledge, and obtain access to markets. International alliances are cooperative arrangements, with cross-border flows and linkages that utilize resources from autonomous organizations headquartered in separate countries (Parkhe, 1991). The general intent of strategic alliance partners is to establish and maintain a long-term cooperative relationship in order to compete more effectively with firms outside the relationship (Jarillo, 1988; Walker \& Poppo, 1991).

Strategic alliances have become increasingly important, but a high level of dissatisfaction with

We acknowledge the helpful comments of Paul Beamish, Jean-Francois Hennart, Andrew Inkpen, Harry Lane, and Thomas Roehl on earlier versions of this work. We also acknowledge the assistance and support of Bert Cannella, Peter Dacin, Javier Gimeno, David Hofmann, Carlos Ruiz, and Roberto Solano. Finally, we gratefully acknowledge the financial support provided by the Center for the Study of Western Hemispheric Trade. actual outcomes relative to expectations has been reported, and many are not successful (Madhok \& Tallman, 1998; Park \& Russo, 1996). Although it is difficult to identify precise failure rates, Hennart, Kim, and Zeng (1998) argued that international strategic alliances are likely to have high dissolution rates. Therefore, the decision to form an alliance is a critical one. After a firm has made the decision to engage in an alliance, its selection of an appropriate partner is the next critical decision (Hitt, Tyler, Hardee, \& Park, 1995). Koot (1988) argued that the partner selection process is difficult but also critical to alliances' success. Some research exists on partner selection (Geringer, 1988; Lane \& Beamish, 1990; Saxton, 1997), but more research is required to explain the basis on which firms select partners. Therefore, in this research we examined international strategic alliance partner selection. In particular, we focused on the differences in partner selection priorities between emerging and developed market firms.

Partner selection does not occur in a vacuum. Much firm behavior is nested, or embedded in a broader political, economic, and social context that shapes action (Dacin, Ventresca, \& Beal, 1999). We 
focused on international strategic alliances formed between firms in emerging and developed market contexts. Emerging markets have become a critically important global phenomenon, and there is need for more research on them. In particular, there has been little research on strategic alliances with partners in emerging markets (Lee \& Beamish, 1995). Beamish (1994) argued that joint ventures, the most common form of strategic alliance, are the dominant strategy used in emerging markets by multinational firms. Specifically, we examined the alliance partner selection characteristics of firms from three emerging markets (Mexico, Poland, and Romania) and three developed markets (Canada, France, and the United States). Variation between developed and emerging markets is likely to occur as a function of differences in norms, resources, and infrastructures. Hence, important differences were expected in the partner preferences of firms from each of these different markets.

Our theoretical explanation for the differential partner selection criteria used by firms from emerging and developed markets is largely drawn from the resource-based view of the firm and organizational learning theory. Our study makes several important contributions to the literature on partner selection and the study of strategic alliances in general. First, our results allow for a more complete understanding of the nature of partner selection, suggesting that partners may be selected largely for access to resources and organization learning that can enhance a focal firm's capabilities. Second, this study examines the importance of specific market contexts (emerging versus developed) in explaining differences in partner selection decisions. Finally, our research enhances understanding of how firms' current resource endowments and needs motivate alliance partner selection, thereby adding value to the resource-based literature. Inasmuch as alliances represent a means to acquire critically needed resources and competencies, this study helps scholars to further understanding of the development (that is, learning) of capabilities and exploitation (leveraging) of resources. We begin with a discussion of the theoretical arguments regarding partner selection within emerging and developed market contexts.

\section{THEORY DEVELOPMENT}

We propose that firms search for strategic alliance partners that have resources they can leverage. They can leverage resources that are complementary by integrating them to create synergy. Or firms can learn skills and capabilities from their partners that enhance their own competencies and thus, their competitive advantages. However, the types of resources firms seek to leverage and the capabilities they need to learn will vary with their market context (emerging or developed). Although there may be some similarities in the resources emerging and developed market firms seek from partners, there are differences in the importance each places on certain resources, capabilities, and characteristics.

Resource-based and organizational learning perspectives help explain why firms select particular alliance partners (Barkema, Bell, \& Pennings, 1996). Firms have specific resource endowments (Barney, 1991) but may need additional resources to be competitive in particular markets (Hitt, Nixon, Clifford, \& Coyne, 1999). Such a need is a primary reason for strategic alliances and for the selection of specific alliance partners. Resources of particular interest in cross-border alliances include financial capital, technical capabilities, managerial capabilities, and other intangible assets, such as firm reputation (in the case of emerging market firms). In addition to seeking local market knowledge and access, developed market firms with large resource endowments try to leverage their resources by selecting alliance partners with complementary capabilities and unique competencies. Alliances provide the opportunity to combine the resources of both partners, yet often firms enter alliances to build their own resource endowments. That is, they wish to acquire knowledge and learn new skills and capabilities (Mothe \& Quelin, 1998). Less resource-endowed firms may desire to learn new technical and managerial capabilities, whereas more resource-endowed firms want to gain knowledge of markets and build relationships to provide access to those markets (Khanna, Gulati, \& Nohria, 1998). Thus, the interactive learning opportunities gained from the experiences of partners in an alliance (March \& Levitt, 1999) help firms add to their capabilities, even tacit components, and build their resource endowments (Lane \& Lubatkin, 1998). Resource endowments and organizational learning are particularly important in alliances between developed market firms and emerging market firms. Next, we examine emerging and developed market contexts as related to alliance partner selection.

\section{Emerging versus Developed Market Contexts}

Emerging and developed markets provide a particularly rich setting in which to contrast the firm characteristics used in partner selection. For example, differences in the nature of formal and informal institutions in these two contexts affect the extent of uncertainty and ambiguity in resource 
decisions. Over time, formal institutions shape the informal rules by which organizations operate. The relative economic and social stability in developed countries promotes the development and acceptance of rules of exchange. In contrast, the economic and sometimes social instability in emerging markets produces ambiguity and uncertainty regarding the rules of exchange; in this context, the rules are largely emergent (North, 1990; Pedersen \& Thomsen, 1997).

Additionally, firms from developed countries have longer established repertoires for alliance activity than firms from emerging markets, which usually have less experience in exploring and attempting to exploit partnership opportunities. In emerging markets, the strategic alliance is a relatively new form of organizing (Lewin, Long, \& Carroll, 1998). Also, important differences in the underlying institutional infrastructures of emerging and developed markets affect managers' strategic orientations (Garten, 1996). Luthans, Patrick, and Luthans (1995) suggested that even countries that are geographically proximal can be economically, politically, and culturally distant in significant ways.

Finally, although emerging economies have grown at a stronger pace than most developed country economies, many of the businesses in emerging markets are young or recently privatized (DeCastro \& Uhlenbruck, 1997), and their resource endowments are unlikely to be strong. Thus, emerging market firms may use alliances as a means of acquiring tangible and intangible resources to develop their capability to compete in their domestic and global markets with multinational firms from other countries. Firms from developed countries tend to have richer resource endowments, but they nevertheless also search for partners with specific resources, tangible and intangible, to complement their own resource bases. Child and Faulkner stated that "when one of the partners... comes from an emerging country and the other from a highly developed economy, their configuration of objectives ... will almost certainly differ from that in the case of partners from two developed countries" (1998: 297). Thus, it is important to consider the different contexts in which strategic alliance partner selection decisions are embedded. We now present hypotheses on partner selection criteria in emerging and developed market contexts.

\section{Hypotheses}

In emerging markets, the economic and institutional infrastructure for distributing capital often is not well developed. Experienced investors are lacking, and disclosure laws are weak or nonexistent. Likewise, financial markets are also generally in their formative stages. A high potential for economic growth may exist-perhaps greater than that in many developed countries-but volatility and high risks are also present. Given poorly developed financial markets, weak institutions for distribution of capital, and volatility in economic development, capital generally has low availability and high cost in emerging market countries. These conditions produce a capital gap between firms from emerging market countries and firms based in developed markets (Svetlicic \& Rojec, 1994). To compete effectively, firms from emerging market countries need access to capital at a reasonable cost. A strategic alliance with a partner having access to such capital can help an emerging market firm to circumvent the capital market problems noted above. Access to capital is an important resource.

Developed market firms are also interested in the financial assets of partners. Despite the opportunities in and the potential sizes of many emerging markets (such as certain Asian countries, Latin America, and Eastern Europe), multinational firms from developed market countries evaluate such investments on a comparative basis, as part of global decisions (Clegg, Kamall, \& Leung, 1996). Thus, these firms carefully evaluate the potential returns on investments in an international market. They may be particularly sensitive to investments in emerging markets because of their risks, and so they will also examine the financial assets of potential partners. Partners that are financially healthy and require less capital and financial investment from a developed market firm are preferred. Additionally, many developed market firms operate in more mature financial markets that often penalize small returns. Therefore, developed market firms frequently emphasize maximization of shareholder wealth over other goals (Jensen, 1993).

Therefore, both emerging market and developed market firms likely place importance on the financial assets of potential partners. Alternatively, financial capital is a basic need for competition and survival in international markets. For emerging market firms, the access to this capital and its costs may be a matter of survival. Therefore, taking a resource-based perspective, we expected emerging market firms to place a significantly higher emphasis on the financial assets of partners than developed market firms. These arguments lead to the following hypothesis:

Hypothesis 1. Although emerging market firms and developed market firms both place impor- 
tance on the financial assets of partners, executives from emerging market firms emphasize financial assets more strongly as a criterion in selecting international strategic alliance partners.

There tends to be a technology gap between firms from emerging markets and firms from more developed markets (Svetlicic \& Rojec, 1994). Because this gap is often quite large, firms from emerging market countries, such as those in Eastern Europe, cannot compete in product technologies with firms from developed market countries. They cannot develop or offer new and sophisticated products in sufficient quantity and quality to be competitive with firms from other countries. Thus, emerging market firms seek access to new technology in order to develop products and, perhaps more importantly, to efficiently build products that can be competitive (Gillespie \& Teegen, 1995). In fact, Svetlicic and Rojec (1994) suggested that emerging market firms often try to narrow the gap by placing more emphasis on gaining and applying new technologies to produce products that can compete with more sophisticated technological leaders. Thus, these firms need to enhance their technological know-how quickly and can do so by selecting alliance partners that have cutting-edge technology. Additionally, emerging market firms may not have the sophisticated information hardware and software possessed by most developed market firms. Thus, emerging market firms may desire access to multiple forms of technological capabilities. For example, securities exchanges from emerging market countries have engaged in a wave of strategic alliances with more established exchanges in developed markets to gain access to technological capabilities (Szyliowicz, Dacin, \& Ventresca, 1999). In light of these arguments, we would expect emerging market firms to select partners with technological capabilities from which they can learn in order to build their own technological capabilities. Building such capabilities will add to their resource endowments. Therefore, emerging market firms are seeking to learn from the experience and knowledge of others, as March and Levitt (1999) suggested.

In contrast, developed market firms normally have relatively sophisticated technologies that provide firm-specific technological advantages. Often these technologies are based on country-specific advantages (Lecraw, 1984). Thus, developed market firms rarely emphasize the technological capabilities of potential alliance partners. We therefore would expect emerging market firms to more strongly emphasize the technological capabilities of potential partners than will developed market firms:

Hypothesis 2. Executives from emerging market firms more strongly emphasize technological capabilities in selecting international strategic alliance partners than do executives from developed market firms.

In emerging market firms, management capabilities and decision-making processes are often not well developed (Lyles \& Baird, 1994). Many of these firms are young, with executives who have little managerial experience or experience in formerly state-owned enterprises that have been recently privatized. Managerial practices that were successful in stable and predictable planned economies are no longer effective (Shama, 1993). In the newly privatized firms, managers generally have little experience in managing market-oriented organizations (McDonald, 1993). Formerly insulated from the rigors of the market by state protection, they have not had much opportunity to deal with market pressures and competition. For example, Stoever (1996) noted that one of the key resources needed in Poland was the skill to manage enterprises in a market economy. Emerging market firms often need managerial capabilities and know-how in order to effectively compete in their domestic markets and, even more, in international markets. Additionally, these firms often have little exposure to modern management concepts, techniques, and processes. For example, decentralization of authority is important in modern competitive firms so that decisions can be made rapidly and by those who have appropriate knowledge. However, decentralization is a relatively alien concept in most state-owned enterprises (Lau, 1998). Because of the need to compete in market-oriented economies and with more managerially sophisticated competitors, executives from emerging market firms will seek partners with strong managerial capabilities. The partners' capabilities can be used to compensate for the emerging market firms' deficits. Of equal importance, emerging market firms can learn from their partners, thereby enhancing their own managerial capabilities, (March \& Levitt, 1999) and broadening their resource endowments.

Undoubtedly, developed market firms also prefer partners who have effective managerial capabilities. In alliances with emerging market firms, however, developed market firms are likely to provide the primary managerial expertise; although they desire managerial capabilities in potential partners, they also generally have the capability to compensate for a partner's deficiencies. In contrast, for emerging market firms managerial capabilities are critical if they are to compete effectively in domes- 
tic and international markets. As a result, we would expect emerging market firms to place stronger emphasis on the managerial capabilities of potential partners than developed market firms.

Hypothesis 3. Executives from emerging market firms emphasize managerial capabilities more strongly in selecting international strategic alliance partners than do executives from developed market firms.

If emerging market firms are new or newly privatized, they may have special needs for legitimacy and other intangible resources in the marketplace (such as product, capital, supply, and labor markets). Firms commonly develop links with strategic partners to enhance their own reputations and images. Obtaining a partner with a strong positive reputation can help provide emerging market firms with legitimacy and prestige in the marketplace. In fact, establishment of legitimacy through alliances can contribute to the success of foreign ventures (Beamish, 1988; Shan \& Hamilton, 1991). Recent evidence suggests that a firm's reputation sometimes plays an important role in alliance partner selection (Dollinger, Golden, \& Saxton, 1997). Reputation and legitimacy are significant intangible assets that can bestow important advantages to firms, in the form of enhanced capabilities to attract and retain customers, suppliers, business partners, and financial resources (Fombrun \& Shanley, 1990). Such resources are often critical to competitive advantage. Thus, executives from emerging market firms are likely to weigh intangible assets, such as a potential partner's reputation, heavily (Eisenhardt \& Schoonhoven, 1996).

Developed market firms also prefer partners with strong, positive intangible resources. They evaluate potential partners having attractive reputations more positively than those without such reputations. They have a lesser need for legitimacy in general, but they are likely to search for partners that provide legitimacy in local markets where the developed firms may not have established reputations. Still, developed market firms bring their brand names and reputations to alliances. Thus, they may emphasize the intangible assets of partners less than do emerging market firms. Intangible resources such as reputation and legitimacy are more critical to emerging market firms because they enhance their access to other resources such as customers, financial resources, and future alliance partners that may be necessary to gain competitive parity or a competitive advantage. Furthermore, emerging market firms with little alliance experience may select partners with strong positive reputations to reduce the perceived risk in the market.
Thus, we would expect emerging market firms to emphasize the importance of intangible assets more strongly in selecting alliance partners than developed market firms.

Hypothesis 4. Executives from emerging market firms more strongly emphasize intangible assets in selecting international strategic alliance partners than do executives from developed market firms.

Although selecting partners who have strong managerial and technical capabilities provides the opportunity for knowledge transfer (Dyer \& Singh, 1998), it does not guarantee that such transfer will occur. In order to learn, firms must have an appropriate absorptive capacity (Cohen \& Levinthal, 1990; Dyer \& Singh, 1998). Prior learning and a set of learning skills provided by learning experiences similar to the partner's provide the capacity to absorb related knowledge. However, acquired knowledge is often specific to the context from which it is derived (Delios \& Beamish, 1998). Most emerging market firms will not have learning experiences similar to those of a partner from a developed country. Developed market firms are likely to have a greater number and broader range of learning experiences. As a result, emerging market firms may find it difficult to learn managerial and technological capabilities from their partners because of inadequate absorptive capacity. For them to acquire such capabilities may require special actions on the part of their partners. In particular, a partner must be willing to share its expertise. First, the partner may have to help the other firm develop an adequate absorptive capacity by working in tandem to provide the necessary experience. After the partner's absorptive capacity is developed, the necessary knowledge can be transferred. Thus, we would expect executives from emerging market firms to search for and select partners who are willing to share their capabilities and, perhaps, to make special efforts to help their partners acquire these capabilities.

Developed market firms are much more likely to have the absorptive capacity to learn new skills and capabilities. Although there is less that they can learn from emerging market firm partners, they may desire to acquire knowledge about local markets. They are less likely to learn managerial and technical capabilities from emerging market firms. As a result, we would expect emerging market firms to more strongly emphasize the willingness of a potential partner to share its capabilities than will developed market firms. 
Hypothesis 5. Executives from emerging market firms more strongly emphasize a willingness to share expertise in selecting international strategic alliance partners than do executives from developed market firms.

Of particular importance to developed market firms is the ability to leverage their current resources. As a result, these firms search for partners that have complementary capabilities (Johnson, Cullen, Sakano, \& Takenouchi, 1996). In order to integrate partners' resources, as suggested by Mothe and Quelin (1998), the partners must have complementary capabilities. In fact, Dyer and Singh (1998) argued that to generate rents from resources may require a firm to use those resources in conjunction with complementary resources from another firm. To do so, they suggest, firms must be able to identify and evaluate potential complementarities with partners and to assess the benefits of those resource complementarities. In support of those arguments, Shan and Hamilton (1991) found that complementarity of resources between domestic and foreign firms was critical to the formation of cross-border alliances in biotechnology. Dyer and Singh (1998) suggested that partners' resources may be more valuable, rare, and difficult to imitate (Barney, 1991) when used in combination than when used separately by the individual partners. Although developed market firms are likely to emphasize the importance of complementary capabilities in selecting alliance partners, most of the arguments suggest that all firms can and do search for complementary capabilities in alliance partners. Therefore, we would expect emerging market firms to emphasize complementary capabilities as well. Although the types of capabilities desired may vary across developed and emerging market firms, in each case, the complementarity of those capabilities to the focal firm's resources and capabilities may be critical for achieving a competitive advantage and thereby alliance success. Thus, we expected both developed and emerging market firms to strongly emphasize complementary capabilities as a criterion in selecting potential alliance partners.

Hypothesis 6. Executives from developed and emerging market firms strongly emphasize complementary capabilities in the selection of international strategic alliance partners.

Beamish (1994) suggested that a primary criterion for developed market firms is market knowledge and access. For many developed market firms, a strategic alliance represents a first entry into an emerging market. Partnering with a local firm may provide a multinational firm with access to customers and channels of distribution and with better knowledge of the customers, local markets, local culture, and idiosyncratic local government policies and regulations. Therefore, developed market firms are likely to emphasize market knowledge and access in their selection of international strategic alliance partners. In this way, emerging market firms provide resources (access to local markets) and help developed market firms learn (local market knowledge). By gaining knowledge about local markets, developed market firms improve their resource endowments.

On the other hand, alliances between developed market firms and emerging market firms are largely concentrated in the emerging market firms' domestic markets or local regions. Thus, emerging market firms are less likely to emphasize local market knowledge and access in the selection of potential partners. Therefore, we would expect developed market firms to more strongly emphasize local market knowledge and access when selecting international strategic alliance partners than emerging market firms.

Hypothesis 7. Executives from developed market firms more strongly emphasize market knowledge and access in the selection of international strategic alliance partners than do executives from emerging market firms.

Developed market firms are particularly sensitive to actions that facilitate gaining and/or maintaining a competitive advantage. An important criterion for gaining and sustaining a competitive advantage is having unique resources (Barney, 1991). As a result, executives from developed market firms search for potential partners with unique (rare) competencies that can be leveraged in an alliance to gain a competitive advantage. This is particularly true where the developed market firm has resources that are complementary to the unique competencies and can be used to leverage the partner's unique competencies to create a competitive advantage for a new venture and/or for both partners in other forms of alliance (Sarkar, Aulakh, \& Cavusgil, 1998). They may also wish to learn these unique competencies to enhance their own resource endowments. Therefore, developed market firms can be expected to emphasize unique competencies in their selection of international strategic alliance partners.

Emerging market firms also likely desire partners with unique competencies because they have a higher probability of building a competitive advantage through an alliance. However, because of the other more specific resource needs of most emerg- 
ing market firms (described earlier), they are more likely to emphasize other resources and capabilities over unique competencies in the selection of international strategic alliance partners. Therefore, we would expect developed market firms to emphasize unique competencies more strongly than emerging market firms in the evaluation and selection of alliance partners.

\section{Hypothesis 8. Executives from developed mar- ket firms more strongly emphasize unique competencies in the selection of international strategic alliance partners than do executives from emerging market firms.}

In summary, in this study we sought to examine desired partner characteristics for emerging market and developed market contexts. We expected firms from both contexts to emphasize several criteria. However, because of resource needs, learning opportunities, and other contextual factors, emerging and developed market firms will differentially emphasize certain criteria. Next, we explain the methods that we used to obtain data from developed market and emerging market firms.

\section{METHODS}

\section{Sample}

Data were collected through a specially designed survey instrument completed by executives from 202 firms, 89 of which were based in developed market countries and 113 of which were based in emerging market countries, and through semistructured interviews with executives from 24 of the firms in three of these countries. Firms from Mexico, Poland, and Romania represented emerging markets, and firms from Canada, France, and the United States represented developed markets. We selected countries from two regions of the world (North America and Europe) to control for potential regional geographic idiosyncrasies. Thus, the samples from both the emerging and developed markets contained firms from both geographic regions. Target firms for the sample were those that had recently (within the last three years) participated in international strategic alliances. Identification of these firms varied by country. For example, sources used to identify U.S., Canadian and, to some degree, Mexican firms participating in international strategic alliances included the IAC Incite database, the F\&S Index-International databases, Securities and Exchange Commission (SEC) filings, ABI Inform, the Wall Street Journal Index, the National Trade Database, and the Mexican Chamber of Commerce Directory. French firms involved in recent international strategic alliances were identified using Fusions $\&$ Acquisitions and a screening of the business sections of the major French newspapers. There are no systematic sources that identify all alliances. "Triangulation" of sources was used to identify target firms for the sample where possible. The lack of a systematic source resulted in a nonrandom sample.

In Poland and Romania, no data sets identifying international strategic alliances were available. Thus, professional contacts were used to identify such firms in both countries. The Mexican sample was also supplemented through professional contacts.

Executives from Canadian, French, and United States firms were contacted by telephone and asked to participate. A special effort was made to identify and contact the executive in each firm who was directly responsible for international strategic alliances. The rate of participation was 23 percent of those contacted. This rate of participation is due to the fact that high-level executives were targeted as respondents, the instrument was 31 pages long (although not difficult or time consuming to complete), and most of these executives were involved in a substantial amount of international travel. Our response rate compares favorably with those of other studies using surveys of top executives; Gaedeke and Tootelian (1976) forecasted a 20 percent response rate from surveys of top executives. Our response rate was greater than Nayyar's (1993: 20.1 percent) and compares favorably with other top executive response rates (e.g., Finkelstein, 1992). Given that the mean respondent reported directly to the CEO and thus was one level below the CEO (the mean levels below the CEO were 1.18 for both the emerging and developed market samples), our sample respondents can be classified as top executives. In addition, several respondents were CEOs. We also conducted some tests to ensure the representativeness of the sample firms, where secondary data were available. We found no differences in the number of employees or total sales between responding and nonresponding firms in the Canadian and U.S. samples.

Mexican executives are reluctant to complete surveys from foreign (and domestic) sources. They are more comfortable participating in studies when they have developed some trust in the party conducting the survey; this trust requires a prior relationship or an association with a legitimating entity, such as a respected Mexican university. Even with legitimacy, personal contact is important to gain cooperation. Likewise, personal contact is important in Poland and Romania. Both are formerly Communist countries where past surveys often in- 
volved political motives; thus, executives are suspicious and reluctant to complete surveys. As a result, personal contact from trusted professionals either prior to or at the time of administration was necessary in these countries. Use of these personal contacts produced a high participation rate, greater than 70 percent across the three countries.

Data were collected over the period 1995-98. The sample firms from developed markets had an average size of 11,265 employees and had participated in a mean 43 prior strategic alliances. The average firm size in the emerging market sample was 1,356 employees, and there was a mean of 9 prior strategic alliances. As expected, the developed market firms were larger and had more alliance experience than the emerging market firms. With regard to industry, 21 percent of all firms were in natural resources, 33 percent were in services, 38 percent were in manufacturing, and 8 percent were in hightechnology industries.

\section{Instrument}

The survey instrument contained instructions for completion, demographic questions on respondent and firm, definitions of the partner selection criteria, and 30 cases describing 14 characteristics of potential alliance partners. The characteristics of potential alliance partners were identified by a thorough review of the related research and literature on international alliances and partner selection and based on the theoretical arguments presented earlier herein. The characteristics were then reviewed with executives from three different countries to ensure that the list was complete and that all characteristics were potentially relevant criteria for alliance partner selection. This process yielded these 14 criteria: financial assets, complementarity of capabilities, unique competencies, industry attractiveness, cost of alternatives, market knowledge/access, intangible assets, managerial capabilities, capabilities to provide quality products/ services, willingness to share expertise, partner's ability to acquire your firm's special skills, previous alliance experience, special skills that you can learn from your partner, and technical capabilities. ${ }^{1}$ The instrument was presented in English to

${ }^{1}$ The specific definitions of the criteria are not included because of length considerations. However, they are available from the authors. Additionally, because of the nature of this research (its focus on emerging market versus developed market contexts), types of alliances were not differentiated. Specific partner selection criteria may vary by type of alliance. both the U.S. and Canadian managers (all managers were anglophones) and was translated into Spanish, French, Polish, and Romanian. Alvarez (1998) suggested that knowledge is institutionally embedded. Therefore, the non-English versions of the instrument were back-translated by an independent source to ensure comparability of the two versions.

The design of the instrument was based on policy capturing, a concept derived from social judgment theory in social psychology. Slovic and Lichtenstein (1971) argued that policy capturing does a remarkably good job of capturing human judgment policies. Stumpf and London (1981) recommended it to assess decision models where multiple criteria are used. Argyris and Schon (1974) argued that managers cannot accurately describe the policies that underlie their decisions (such espoused theory is captured through typical surveys and directive interview procedures). Rather, Argyris and Schon suggested that one can only accurately identify the policies used in decisions by observing managers' decisions, or theory in use. This argument is the basis of policy capturing. Respondents are presented with a series of case situations and asked to make decisions on the basis of the information presented. The multiple criteria are varied across the cases. From the specific decisions made (constituting the dependent variable), the criteria used by the respondent (constituting the independent variables) can be identified statistically (Slovic \& Lichtenstein, 1971). Importantly, this method avoids the problems of retrospective bias common with some survey techniques (e.g., Golden, 1992). ${ }^{2}$

The particular policy-capturing approach used in this study was developed by Hitt and Middlemist (1979). It has been used in a variety of settings, such as the selection of managers (Hitt \& Barr, 1989), acquisitions decisions (Hitt \& Tyler, 1991; Hitt, Dacin, Tyler, \& Park, 1997), and technology collaboration decisions (Tyler \& Steensma, 1998). Hitt and Middlemist (1979) conducted follow-up interviews to assess the validity of this approach. Their results showed that the methodology effectively captured managers' judgment policies regarding key decisions (in their case, criteria used to measure the effectiveness of major units within an organization). The post hoc interviews with top executives in the organization studied showed that

\footnotetext{
${ }^{2}$ Certainly, all methods have their limitations. Because the policy-capturing instrument cannot capture the contextual complexity of alliance partner selection, the resulting criteria may represent more ideal partner characteristics.
} 
policies they identified closely matched managerial practices.

In the construction of the cases, we randomly assigned (using a random number generator) the levels of the independent variables in each case. This was done to avoid multicollinearity. We examined the correlations of the 14 independent variables to ensure the randomization indeed prevented multicollinearity. The process was effective, as the highest common variance between any two of the 14 independent variables was .13. Also, in the construction of the cases, we had to ensure that the variance of each of the 14 variables was balanced. This required that the randomized assignment of levels to each of the variables be recalculated several times until each of the variables had a variance that was relatively equal to the variance of all of the other variables. This was necessary to ensure that each variable had a relatively equal probability of having an effect on the dependent variable.

\section{Pilot Study}

A pilot study was conducted to test the efficacy of the survey instrument. Specifically, we were interested in the perceived validity of the instrument and cases, the clarity of the instructions, the efficacy of the variables and their definitions, and the time required to complete the instrument. Nineteen executives from three countries (Canada, Mexico, and the United States) participated in the pilot study. From their feedback, we determined that the instrument usually required no more than 30 minutes to complete. The variables were identified as efficacious for describing strategic alliance partners, but some of the definitions needed clarification to ensure effective communication to the managers completing the instrument. Thus, we rewrote three of the definitions to improve their clarity.

\section{Variables}

Independent. The 14 partner firm characteristics served as the independent variables for analyses. We constructed the cases by varying the levels of these 14 independent variables randomly over five levels, from 1 (low) to 5 (high). Thus, the cases presented an evaluation of a potential strategic alliance partner on the basis of these 14 criteria.

Dependent. The dependent variable was a twoitem scale. Executives were asked to rate each of the 30 potential partners described in the cases on a seven-point Likert-type scale on (1) the attractiveness of the firm described as a partner and (2) the probability that the respondent would recommend an alliance with the firm described. We averaged these two items to form the dependent variable. This scale had high internal reliability, as the correlation between the two items was .87 .

Control. Four variables were used as controls in the analyses because of their potential effect on partner selection. These variables are industry, size, prior alliance experience, and country.

Hitt and Tyler (1991) found that industry affected the criteria used to make acquisition decisions. A number of others have argued the importance of industry in determining the strategies employed by firms (e.g., Henderson \& Mitchell, 1997; McGahan \& Porter, 1997). Therefore, type of industry was controlled in the analyses. A firm's industry was categorized into one of the four groups: natural resources, basic manufacturing, service, and high technology. Each industry type was transformed into a dummy variable $(0,1)$, with high technology treated as a zero to avoid a unitary matrix.

A firm's size can affect its market power and thus its ability to dominate the partners in an alliance. Because of this, large firms are likely to seek different types of characteristics than smaller firms in alliance partners. We controlled for firm size in our analyses, calculating it as the logarithm of the total number of employees. Total number of employees is often highly correlated with total annual revenues. Because our sample contained firms from six different countries operating with six different currencies, using number of employees avoided accuracy concerns in translating currency values.

The third control variable was alliance experience. As firms gain more experience with strategic alliances, they should better learn the characteristics that they desire in alliance partners. Furthermore, a firm with more strategic alliances may search for specialized alliance niches, requiring different types of partners (Geringer, 1988). For these reasons, we controlled for the prior alliance experience of a firm, calculated as the total number of alliances in which it had engaged.

The fourth control variable was country. Within each context (emerging and developed markets), there might be different levels of economic development and different institutional structures. Furthermore, national cultures might vary. Finally, the number of firms sampled varied somewhat by country. To ensure that the results could be attributed to the general market contexts, we controlled country by inserting dummy variables $(0,1)$ for each country (minus one in each grouping to avoid a unitary matrix). 


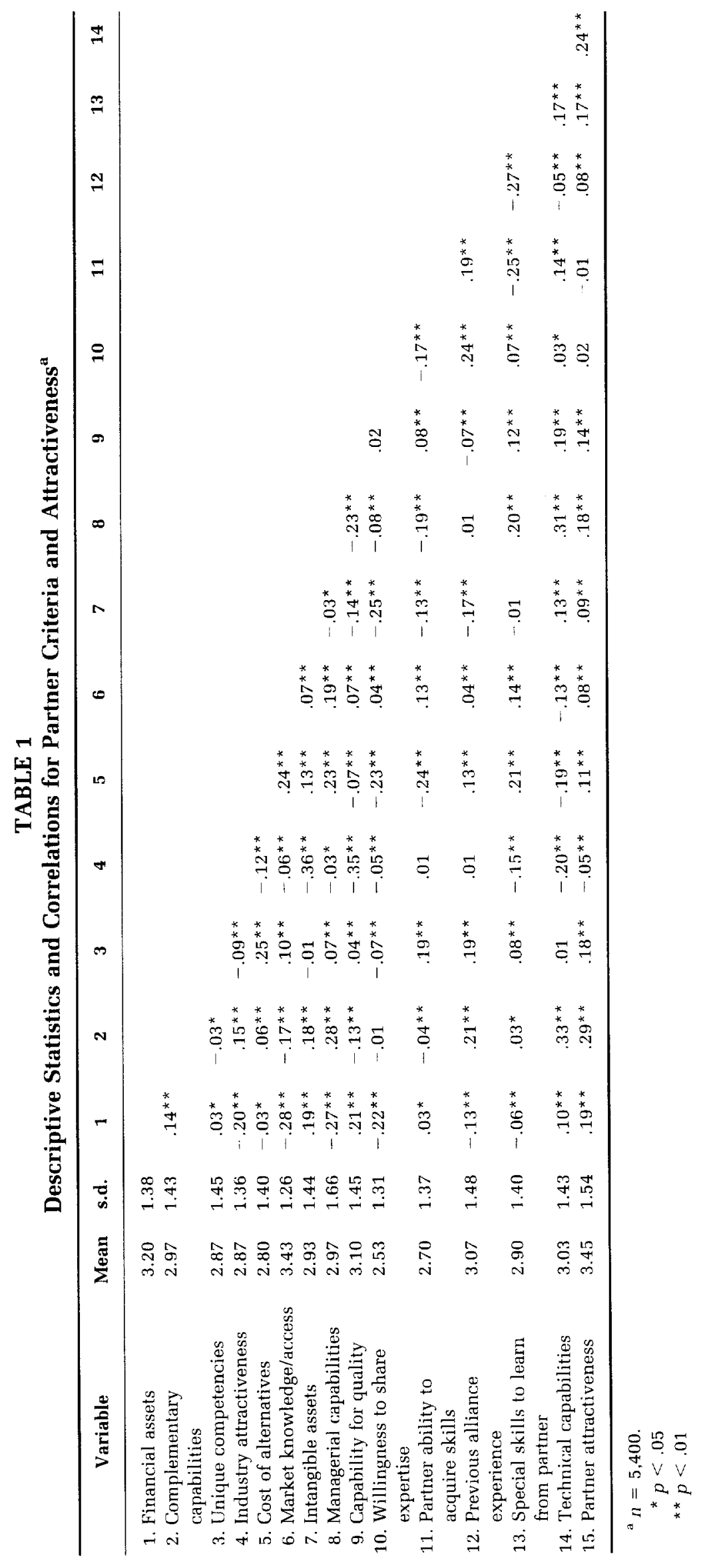


TABLE 2

Descriptive Statistics and Correlations for Control Variables ${ }^{\text {a }}$

\begin{tabular}{|c|c|c|c|c|c|c|c|c|c|c|c|c|}
\hline Variable & Mean & s.d. & 1 & 2 & 3 & 4 & 5 & 6 & 7 & 8 & 9 & 10 \\
\hline 1. Natural resources & 0.21 & 0.41 & & & & & & & & & & \\
\hline 2. Service & 0.32 & 0.47 & $-.36^{\star *}$ & & & & & & & & & \\
\hline 3. Manufacturing & 0.38 & 0.49 & $-.41^{\star \star}$ & $-.55^{\star *}$ & & & & & & & & \\
\hline 4. Firm size ${ }^{b}$ & 6.07 & 2.50 & .05 & -.08 & .02 & & & & & & & \\
\hline $\begin{array}{l}\text { 5. Alliance } \\
\text { experience }\end{array}$ & 24.67 & 84.22 & .09 & .01 & -.07 & $.21^{* *}$ & & & & & & \\
\hline 6. Canada & 0.17 & 0.37 & -.05 & .03 & -.04 & .03 & .06 & & & & & \\
\hline 7. France & 0.12 & 0.33 & -.11 & -.04 & .09 & $.28^{* *}$ & -.01 & $-.17^{\star}$ & & & & \\
\hline 8. United States & 0.18 & 0.38 & $.18^{*}$ & -.14 & -.03 & $.45^{* *}$ & $.21^{* *}$ & $-.20^{* \star}$ & $-.17^{\star}$ & & & \\
\hline 9. Poland & 0.17 & 0.38 & $-.23^{* *}$ & -.01 & $.18^{*}$ & $-.32^{\star *}$ & -.06 & $-.20^{\star \star}$ & $-.17^{\star}$ & $-.21^{\star *}$ & & \\
\hline 10. Romania & 0.08 & 0.28 & $-.15^{\star}$ & $.26^{* *}$ & -.07 & $-.23^{\star \star}$ & -.06 & -.13 & -.11 & -.14 & -.13 & \\
\hline 11. Mexico & 0.27 & 0.44 & $.26^{\star *}$ & -.03 & -.12 & $-.21^{* *}$ & -.13 & $-.27 * \star$ & $-.23^{\star \star}$ & $-.28^{\star \star}$ & $-.28^{* \star}$ & $-.18^{*}$ \\
\hline
\end{tabular}

$a n=180$

${ }^{b}$ Logarithm.

${ }^{*} p<.05$

$\star \star p<.01$

\section{Interviews}

We conducted interviews with executives from 24 firms participating in the study. We had three primary purposes in the interviews. Like Hitt and Middlemist (1979), we used the interviews to validate the results collected with the policy-capturing instrument. Second, the interviews were designed to gather information to help us interpret the results obtained. Third, we sought to unmask and clarify issues related to partner dynamics not easily discernible from our policy-capturing data.

We developed a set of interview questions, pretested the interview protocol, and adjusted the ordering and structuring of questions. We also incorporated additional questions, as deemed appropriate, that were unique to the firms in which executives were interviewed. An attempt was made to have two interviewers present for all interviews. Each interviewer took independent notes, and these were transcribed shortly after each interview. We also attempted to interview all the partners involved in a particular alliance. Thus, we have a set of largely matched interviews with partners. The interviews were one to two hours in length and were conducted shortly after completion of the policy-capturing instrument (but prior to analysis of the survey data). We interviewed managers regarding several areas, including their perceived strengths and competencies, previous and current alliance experiences, perceptions about alliance outcomes, criteria and processes for partner selection, and sharing, transfer, and protection of firm knowledge and skills. The results of the interviews supported the efficacy of our models for emerging and developed market firms (described next).

\section{RESULTS}

Tables 1 and 2 present correlations and sample statistics for all variables used in the study. After cleaning the data, we had 85 developed market firms (Canadian $n=30$, French $n=23$, U.S. $n=$ 32) and 97 emerging market firms (Mexican $n=49$, Polish $n=33$, Romanian $n=15$ ) in the sample. The analyses are based on these data.

To test Hypotheses 1-8, we first developed models for the emerging market and the developed market firms using hierarchical linear modeling. The results of these analyses are shown in Table 3. The policy-capturing approach provides 30 observations per individual. Therefore, there were 2,910 observations for emerging market firms and 2,550 observations for developed market firms. This amount of observations creates a significant number of degrees of freedom for analytical purposes. However, the 30 observations for each individual cannot necessarily be considered independent as they may be autocorrelated. Hierarchical linear modeling controls for potential autocorrelation and heteroskedasticity (Hofmann, 1997). Hierarchical linear modeling involves a two-stage analytical process and is particularly appropriate for use with policy-capturing data. It controls for withinrespondent variance and allows examination of between-respondents and group effects (Вryk \& Raudenbush, 1992). The coefficients can be interpreted like those of ordinary least squares (OLS) regression analysis. In fact, because our independent variables had relatively equal variances, the resulting coefficients largely proxy standardized coefficients in which the relative weights can be interpreted. 
TABLE 3

Results of Hierarchical Linear Modeling Analysis for Type of Market and Partner Criteria ${ }^{a}$

\begin{tabular}{|c|c|c|}
\hline Variable & $\begin{array}{l}\text { Emerging } \\
\text { Markets }\end{array}$ & $\begin{array}{l}\text { Developed } \\
\text { Markets }\end{array}$ \\
\hline \multicolumn{3}{|l|}{ Control } \\
\hline Intercept & $3.21^{\star} \quad[0.30\}$ & $3.15^{\star \star}(0.13)$ \\
\hline Natural resources & $0.41 \quad(0.28)$ & $-0.22^{\star *}(0.09)$ \\
\hline Service & $0.27 \quad(0.26)$ & $-0.13 \quad(0.08)$ \\
\hline Manufacturing & $0.13 \quad(0.26)$ & $-0.11 \quad(0.08)$ \\
\hline Firm size ${ }^{b}$ & $0.05^{+} \quad(0.03)$ & $0.02^{\star} \quad(0.01)$ \\
\hline Alliance experience & $-0.02^{\star *}(0.00)$ & $0.00 \quad(0.00)$ \\
\hline Poland-France & $0.07 \quad(0.13)$ & $-0.01 \quad(0.06)$ \\
\hline Romania-Canada & $0.65 * *(0.16)$ & $0.20^{\star *}(0.06)$ \\
\hline \multicolumn{3}{|l|}{ Partner criteria } \\
\hline Financial assets & $0.35^{* *}$ & $0.18^{\star \star}$ \\
\hline Complementary capabilities & $0.14^{\star *}$ & $0.22^{\star \star}$ \\
\hline Unique competencies & $0.08^{\star *}$ & 0.21 ** \\
\hline Industry attractiveness & 0.11 ** & $0.21^{\star *}$ \\
\hline Cost of alternatives & 0.00 & $0.07^{\star \star}$ \\
\hline Market knowledge/access & $0.14^{* *}$ & $0.07^{\star}$ \\
\hline Intangible assets & $0.09^{* *}$ & $0.13^{* *}$ \\
\hline Managerial capabilities & $0.14^{* *}$ & $0.20^{* *}$ \\
\hline Capability for quality & 0.18 ** & $0.21 * *$ \\
\hline $\begin{array}{l}\text { Willingness to share } \\
\text { expertise }\end{array}$ & $0.11^{* *}$ & $0.13^{* *}$ \\
\hline $\begin{array}{l}\text { Partner ability to acquire } \\
\text { skills }\end{array}$ & 0.01 & 0.04 \\
\hline $\begin{array}{l}\text { Previous alliance } \\
\text { experience }\end{array}$ & $0.08^{* *}$ & $0.08^{* *}$ \\
\hline $\begin{array}{l}\text { Special skills to learn from } \\
\text { partner }\end{array}$ & $0.11^{* *}$ & $0.16^{\star \star}$ \\
\hline Technical capabilities & $0.16^{\star \star}$ & -0.01 \\
\hline
\end{tabular}

a The top portion of the table shows the fixed-effects models; the bottom portion shows the random-effects models. Standard errors are in parentheses.

${ }^{\mathrm{b}}$ Logarithm of number of employees.

${ }^{+} p<.10$

$* p<.05$

$\star * p<.01$

Next, we examined differences between the two models (emerging markets and developed markets) on each criterion. To do so, we again used hierarchical linear modeling (Hofmann, 1997), combining the data for the two groups and testing for statistically significant interaction effects. This required 14 separate models, one for each criterion (Hofmann, 1998 personal communication). When we found such an effect, it suggested that the coefficients on that characteristic varied between the emerging and developed markets. Table 4 shows the $t$-statistics for each of the 14 partner criteria depicting the differences between emerging and developed market firms.

Hypothesis 1 states that emerging market firms more strongly emphasize financial assets in selecting international strategic alliance partners than do developed market firms. The results presented in
TABLE 4

Differences between Emerging and Developed Market Firms

\begin{tabular}{lc}
\hline \multicolumn{1}{c}{ Partner Criteria $^{\mathbf{a}}$} & $\boldsymbol{t}$ \\
\hline Financial assets & $9.82^{\star \star}$ \\
Complementary capabilities & -1.32 \\
Unique competencies & $-5.44^{\star \star}$ \\
Industry attractiveness & $-4.36^{\star \star}$ \\
Cost of alternatives & $-5.28^{\star \star}$ \\
Market knowledge/access & $-3.57^{\star \star}$ \\
Intangible assets & $3.07^{\star}$ \\
Managerial capabilities & -1.37 \\
Capability for quality & $4.34^{\star \star}$ \\
Willingness to share expertise & $2.44^{\star}$ \\
Partner ability to acquire skills & $1.90^{+}$ \\
Previous alliance experience & $-2.32^{\star}$ \\
Special skills to learn from partner & $-2.32^{\star}$ \\
Technical capabilities & $6.36^{\star *}$ \\
\hline
\end{tabular}

${ }^{a}$ A positive sign suggests that the emerging market coefficient is larger and a negative sign that the developed market coefficient is larger.

$$
\begin{aligned}
{ }^{t} p & <.10 \\
{ }^{*} p & <.05 \\
{ }^{*} p & <.01
\end{aligned}
$$

Table 4 support this hypothesis. Although the results in Table 3 show that financial assets are important in the selection of alliance partners by both emerging and developed market firms, as expected, the emerging market firms more strongly emphasized partners' financial assets. Indeed, not only is the coefficient for financial assets in the emerging market firms' model statistically significant $(p<$ .01 ), it is also the strongest criterion (because of the relatively equal standard errors, the parameter estimates provide an efficient estimate of relative strength).

Hypothesis 2 states that emerging market firms emphasize technical capabilities more strongly than do developed market firms in selecting international strategic alliance partners. The results represented in Table 4 support this hypothesis, showing that the technical capabilities coefficient for emerging market firms is stronger than that for developed market firms. Additionally, the results presented in Table 3 show that the coefficient for technical capabilities is statistically significant $(p<$ .01 ) and among the three strongest partner selection criteria in the emerging market firms' model. Additionally, the coefficient for technical capabilities is not statistically significant in the developed market model.

Emerging market firms were expected to emphasize managerial capabilities more strongly than developed market firms in selecting international strategic alliance partners (Hypothesis 3). Although 
the results presented in Table 3 show that the coefficient for managerial capabilities was strong and statistically significant $(p<.01)$ in the emerging market firm model, the coefficient is equally strong for developed market firms. Furthermore, the results presented in Table 4 show that there are no differences between the two subsamples. Thus, both emerging and developed market firms emphasize managerial capabilities in alliance partner selection. These results do not support Hypothesis 3.

The fourth hypothesis suggests that emerging market firms more strongly emphasize intangible assets in the selection of international alliance partners than do developed market firms. The results presented in Table 4 provide support for this hypothesis, indicating that the coefficient for intangible assets in emerging market firms is statistically different from (and stronger than) the coefficient for developed market firms $(p<.05)$.

Hypothesis 5 states that emerging market firms emphasize the willingness to share expertise more strongly than developed market firms when selecting international strategic alliance partners. The coefficients for willingness to share expertise are statistically significant $(p<.01)$ in both the emerging market and developed firms' models (Table 3), but the results presented in Table 4 show that emerging market firms emphasize this criterion more than developed market firms. Therefore, the results provide support for this hypothesis.

Hypothesis 6 states that developed and emerging market firms equally and strongly emphasize complementary capabilities in the selection of international strategic alliance partners. The results in $\mathrm{Ta}-$ ble 3 support this hypothesis, as the coefficients for complementary capabilities in both models are statistically significant $(p<.01)$. Indeed, this variable is the strongest partner selection criterion in the developed market firms' model. Further support for the hypothesis is provided in Table 4, which indicates no differences in the complementary capabilities coefficients for the emerging and developed market models.

Hypothesis 7 suggests that developed market firms emphasize market knowledge/access more strongly than emerging market firms in selecting partners for international strategic alliances. Although the results in Table 3 show that the coefficients for market knowledge/access are statistically significant for both emerging market and developed market firms, the results presented in Table 4 show that market knowledge/access is a stronger selection criterion $(p<.01)$ for developed market firms than for emerging market firms, providing support for the hypothesis.
Finally, Hypothesis 8 states that developed market firms emphasize unique competencies more strongly than do emerging market firms in selection of international strategic alliance partners. The results provide strong support for this hypothesis. The coefficient for unique competencies is statistically significant $(p<.01)$ in both models but is among the strongest predictors in the developed market firms' model. Importantly, the results in Table 4 show that this criterion is a stronger predictor $(p<.01)$ for developed than for emerging market firms.

The results also suggest that criteria other than those hypothesized may be important in partner selection for international strategic alliances. For example, partners' capability for quality was a strong predictor in both the developed and emerging market firms' models. Interestingly, however, it was a stronger predictor in the emerging market firms' model. Industry attractiveness, cost of alternatives, previous alliance experience, and special skills to learn from a partner were stronger predictors for the developed market firms than for the emerging market firms.

\section{DISCUSSION}

Strategic alliances have become popular among firms throughout the world, and there has been a significant amount of recent research on this form of cooperative strategy. There are a number of potential explanations for the formation of strategic alliances, and a prominent one is that they are a means of entering international markets. However, little is known about factors that lead to success in alliances, and research suggests that a substantial number of alliances produce dissatisfactory results (Madhok \& Tallman, 1998). We argue that a critical step in the success of an alliance is the selection of a partner, but there has been little past research on this phenomenon. Some recent research has linked partner characteristics with strategic alliance success (e.g., Saxton, 1997). However, our results provide a unique contribution to the understanding of partner selection in particular because they suggest that alliance partners may be selected largely for access to resources and organizational learning opportunities that may enhance a focal firm's capabilities. The results also emphasize the importance of context in partner selection decisions. Specifically, we examined the differential partner selection criteria used in emerging and developed market contexts.

Table 5 summarizes the results of this study. The emerging market firms, as expected, more strongly emphasized partners' financial assets, technical capa- 
TABLE 5

Priorities in Selecting Alliance Partners by Market Type ${ }^{a}$

\begin{tabular}{cc}
\hline Importance/Priority $^{\mathbf{b}}$ & Emerging Market Firms \\
\hline Important and differential priority & (1) Financial assets \\
& (14) Technical capabilities \\
(7) Intangible assets \\
(10) Willingness to share expertise \\
(9) Capability for quality
\end{tabular}

Important and similar priority

Important but differentially lower priority

Unimportant
(2) Complementary capabilities

(8) Managerial capabilities
(3) Unique competencies
(4) Industry attractiveness
(6) Market knowledge/access
(12) Previous alliance experience
(13) Special skills to learn from partner

(5) Cost of alternatives

(11) Partner's ability to acquire skills
Developed Market Firms

(3) Unique competencies

(6) Market knowledge/access

(12) Previous alliance experience

(5) Cost of alternatives

(4) Industry attractiveness

(13) Special skills to learn from partner

(2) Complementary capabilities

(8) Managerial capabilities

(1) Financial assets

(7) Intangible assets

(9) Capability for quality

(10) Willingness to share expertise

\footnotetext{
a The rank order for each criterion in the corresponding model in Table 3 is in parentheses.

${ }^{b}$ Importance indicates a statistically significant coefficient; priority indicates statistically different (stronger) coefficients.
}

bilities, intangible assets, and willingness to share expertise than did the developed market firms. Unexpectedly, the emerging market firms also emphasized capability for quality more strongly than did the developed market firms. Alternatively, developed market firms, as expected, emphasized partners' unique competencies and market knowledge and access more strongly than did emerging market firms. Interestingly, the developed market firms also emphasized partners' previous alliance experience, the cost of alternatives, and industry attractiveness, along with special skills to learn from a partner, more strongly than did emerging market firms. Partners' complementary capabilities and managerial capabilities were important and of similar priority to both emerging and developed market firms. The cost of alternatives was unimportant to emerging market firms, and partners' technical capabilities were unimportant to developed market firms. A partner's ability to acquire skills was unimportant to firms from both contexts. The other partner characteristics not mentioned above were important in emerging or developed market firms but were of lower priority (as shown in Table 5).

Clearly, the results of this research show the importance of both tangible and intangible resources in the selection of international strategic alliance partners. The financial assets desired in partners by emerging market firms are largely tangible. The technical and managerial capabilities desired by emerging market firms and the unique competencies, market knowledge, and access desired by de- veloped market firms are largely intangible. In fact, several of these intangible resources are based on tacit knowledge. Most are valuable, and because of their tacit and intangible nature, they are difficult to imitate, thereby providing a basis for a competitive advantage (Barney, 1991).

The results also emphasize the importance of organizational learning as a basis for partner selection. Alliances are perhaps the best means of transferring tacit managerial and technological capabilities (Mowery, Oxley, \& Silverman, 1996). Thus, emerging market firms search for partners from which they can learn managerial and technical capabilities. Alliances allow a firm to get close enough to partners to understand even tacit components of their capabilities (Lane \& Lubatkin, 1998). Developed market firms also seek to gain local market knowledge and perhaps the unique competencies of partners. The focus on organizational learning in alliance decisions is shown by the fact that both emerging and developed market firms placed importance on the willingness of partners to share their expertise and on special skills they could learn from partners. Thus, firms involved in alliances seek to learn from the experience of others, one of the most productive means of organizational learning, according to March and Levitt (1999). Lane and Lubatkin (1998) suggested that this form of organizational learning often has a higher probability of producing a competitive advantage because it allows the transfer of tacit knowledge. Furthermore, other forms of learning 
(such as seminars and written materials) require the information to be fully articulable and thus available to all others (like competitors). Therefore, these other forms of learning are not rare and are less likely to produce a competitive advantage.

Examination of partner selection in emerging market contexts is especially important (Inkpen \& Beamish, 1997). Emerging market firms need technical expertise and financial capital to be competitive, and their economies require these resources to develop and grow. Managerial expertise also seems particularly important in newly privatized firms to help them compete in a free market economy. However, although a significant predictor of partner selection in emerging market firms, management capabilities were of equal importance to developed market firms. Developed market firms largely have the technical expertise needed. Thus, the technical capabilities criterion was unimportant in their selection of partners. Alternatively, many firms in emerging markets need up-to-date technological capabilities to be efficient and produce goods of sufficient quality to compete with international firms in their domestic and global markets. Thus, they search for partners with the technological capabilities they need to enrich their resource endowments.

A major deficit in transitional economies such as Poland and Romania is the lack of financial capital and the lack of infrastructure to provide access to capital. Many firms in these countries therefore develop strategies (for instance, strategic alliances) designed to garner infusions of equity capital (Klich, 1998; Nicolescu, 1998). Although some other emerging market countries have better-developed infrastructures than Poland and Romania, they still need access to more financial capital at a reasonable cost. Mexico is a prime example. The devaluation of the peso and economic conditions in Mexico made it critical for Mexican firms to seek partners with strong financial assets. These firms have been particularly interested in gaining access to capital that has been difficult and costly to obtain from Mexico's capital markets. The Mexican managers interviewed all expressed substantial concerns about the acquisition and use of financial capital. Also, some evidence indicates that capital markets respond favorably to joint venture announcements (Koh \& Venkatraman, 1991; McConnell \& Nantell, 1985). Accordingly, emerging market companies seek financially strong partners to enhance their credibility in domestic capital markets. Such partners, then, increase emerging market firms' resource endowments.

Certainly, emerging market firms are more dependent than developed market firms on partners who are willing to share their expertise and, indeed, to take special actions to help their partners learn new capabilities. Because they often lack the absorptive capacity to learn these new capabilities, emerging market firms need partners that help them develop the capacity to learn and then transfer the required knowledge. Without the capability to learn, attempts to transfer knowledge likely will fail. Perhaps lack of absorptive capacity is one reason for unsuccessful strategic alliances. An inability to acquire new technologies in more sophisticated and changing global markets may increase the probability of an emerging market firm's being locked out of the technologies it needs to compete (Arthur, 1988; Schilling, 1998).

Eisenhardt and Schoonhoven (1996) and Dacin and Oliver (1997) have argued that firms may use alliances to enhance their legitimacy. Thus, they search for partners with strong intangible assets, such as strong reputations. Dollinger and colleagues (1997) found that partner reputation can play a role in alliance partner selection, and Saxton (1997) found that partner reputation affected the success of alliances. Intangible assets may be important to all alliance partners, but legitimacy is often more critical to firms from emerging markets. Thus, these firms develop alliances with partners to enhance their own reputation and image by tapping the reputations of more established partners.

Capability for quality was a more important criterion for partner selection than expected. Both groups of firms in our study emphasized it in partner selection, but the emphasis was even stronger for emerging market firms. The importance of quality for competitiveness in global markets (Sherman \& Hitt, 1996) may be the primary reason. The proliferation of International Standards Organization (ISO) standards worldwide has placed pressure on firms from all countries to improve and maintain their quality. Developed market firms want partners that can produce quality goods. Emerging market firms want partners from whom they can learn to produce higher quality. Acquiring the knowledge to meet international quality standards enhances emerging market firms' resource endowment.

The results suggest that developed market firms attempt to leverage their resources to gain a competitive advantage by searching for partners with unique competencies and local market knowledge and access. Realizing they need partners with market knowledge and access to leverage their resources, developed market firms desire to minimize their transaction costs. The more they have to teach their partners or take control and coordinate their alliances, the greater their transactions costs. It is difficult to transfer firm-specific capabilities (Kogut \& 
Zander, 1992). Partners with more alliance experience and greater managerial capabilities will require less of their partners. Alliance experience coupled with managerial capabilities should reduce the spatial transaction costs of international strategic alliances. Although they minimize the developed market firms' potential transaction costs, they also simultaneously increase the probability of alliance success.

The overall failure rates of strategic alliances have been reported to be quite high, and they are even higher for alliances between firms with home bases in different countries (Hennart \& Zeng, 1997). A problem in international strategic alliances can be the different strategic orientations of the partners (Dacin, Hitt, \& Levitas, 1997; Hitt et al., 1995). In other words, partners' different reasons for entering strategic alliances and different approaches to them may cause conflict in the implementation of the alliances. Strategic orientations may be particularly important in the selection of partners.

In summary, this research puts in place another piece of the puzzle of international strategic alliances. The focus of this study on the criteria used for partner selection has shown that resource-based theories and organizational learning provide prominent explanations for partner selection. This research shows the importance of firms' embeddedness in emerging and developed market contexts for their selection of international strategic alliance partners. The study also suggests that alliance partners are selected largely for access to resources that can be leveraged and capabilities that can be learned. Thus, strategic alliances are used to enhance the resource endowments of focal firms.

Future research should examine how the partner selection criteria used in each context are related to alliance success. Additionally, partner selection is dynamic; should changes in context occur (such as changes in emerging markets) or should the strategic orientations of managers shift, a different set of selection criteria may be employed. Future research should examine whether and how partner selection criteria might vary with different types of strategic alliances. Finally, research is needed to examine the process of acquiring and leveraging resources. Thus, it is important for the managers of alliances to continue to study the process of partner selection, to achieve a rich understanding of the dynamics that contribute to the evolution of partner selection and to better understand the process of acquiring and leveraging resources.

\section{REFERENCES}

Alvarez, J. L. 1998. The sociological tradition and the spread and institutionalization of knowledge for ac- tion. In J. L. Alvarez (Ed.), The diffusion and consumption of business knowledge: $13-57$. New York: St. Martin's Press.

Argyris, C., \& Schon, D. A. 1974 Theory in practice: Increasing professional effectiveness. San Francisco: Jossey-Bass.

Arthur, W. B. 1988. Self-reinforcing mechanisms in economics. In P. W. Anderson, K. J. Arrow, \& D. Pines (Eds.), The economy as an evolving complex system: 9-31. Reading, MA: Addison-Wesley.

Barkema, H. G., Bell, J. H. J., \& Pennings, J. M. 1996. Foreign entry, cultural barriers, and learning. Strategic Management Journal, 17: 151-166.

Barney, J. B. 1991. Firm resources and sustained competitive advantage. Journal of Management, 17: 99-120.

Beamish, P. W. 1988. Multinational joint ventures in developing countries. London: Routledge.

Beamish, P. W. 1994. Joint ventures in LDCs: Partner selection and performance. Management International Review, 34(special issue): 60-74.

Bryk, A. S., \& Raudenbush, S. W. 1992. Hierarchical linear models. Newbury Park, CA: Sage.

Child, J., \& Falkner, D. 1998. Strategies of cooperation. Oxford, England: Oxford University Press.

Clegg, J., Kamall, S., \& Leung, M. 1996. European multinational activity in telecommunications services in the People's Republic of China: Firm strategy and government policy. Management International Review, 36(special issue): 111-127.

Cohen, W. M., \& Levinthal, D. A. 1990. Absorptive capacity: A new perspective on learning and innovation. $\boldsymbol{A d}$ ministrative Science Quarterly, 35: 128-152.

Dacin, M. T., Hitt, M. A., \& Levitas, E. 1997. Selecting partners for successful international alliances: Examination of U.S. and Korean firms. Journal of World Business, 32(spring): 3-16.

Dacin, M. 'T., \& Oliver, C. 1997. The legitimacy of strategic alliances: An institutional perspective. Paper presented at the INFORMS Fall Conference, Dallas.

Dacin, M. T., Ventresca, M. J., \& Beal, B. D. 1999. The embeddedness of organizations: Dialogue \& directions. Journal of Management, 25: 317-356.

DeCastro, J. O., \& Uhlenbruck, N. 1997. Characteristics of privatization: Evidence from developed, less-developed and formerly communist countries. Journal of International Business Studies, 28: 123-143.

Delios, A., \& Beamish, P. W. 1998. Survival and profitability: The role of capabilities in subsidiary performance. Paper presented at the annual Academy of International Business meeting, Vienna.

Dollinger, M. J., Golden, P. A., \& Saxton, T. 1997. The effect of reputation on the decision to joint venture. Strategic Management Journal, 18: 127-140.

Dyer, J. H., \& Singh, H. 1998. The relational view: Coop- 
erative strategy and sources of interorganizational competitive advantage. Academy of Management Review, 23: 660-679.

Eisenhardt, K. M., \& Schoonhoven, C. B. 1996. Resourcebased view of strategic alliance formation: Strategic and social effects in entrepreneurial firms. Organizational Science, 7: 136-150.

Finkelstein, S. 1992. Power in top management teams: Dimensions, measurement and validation. Academy of Management Journal, 35: 505-538.

Fombrun, G. J., \& Shanley, M. 1990. What's in a name? Reputation building and corporate strategy. Academy of Management Journal, 33: 233-258.

Gaedeke, R. M., \& Tootelian, D. H. 1976. The Fortune 500 list-An endangered species for academic research. Journal of Business Research, 4: 283-288.

Garten, J. E. 1996. The big emerging markets. Columbia Journal of World Business, 31(summer): 6-31.

Geringer, J. M. 1988. Joint venture partner selection: Strategies for developed countries. Westport, CT: Quorum Books.

Gillespie, K., \& Teegen, H. J. 1995. Market liberalization and international alliance formation: The Mexican paradigm. Columbia Journal of World Business, 30(winter): $58-69$.

Golden, B. R. 1992. The past is the past-Or is it? The use of retrospective accounts as indicators of past strategy. Academy of Management Journal, 35: 848-860.

Henderson, R., \& Mitchell, W. 1997. The interactions of organizational and competitive influences on strategy and performance. Strategic Management Journal, 18(special issue): 5-14.

Hennart, J.-F., Kim, D.-J., \& Zeng, M. 1998. The impact of joint venture status on the longevity of Japanese stakes in U.S. manufacturing affiliates. Organization Science, 9: 382-395.

Hennart, J.-F., \& Zeng, M. 1997. The differences in the national origin of partners affect the longevity of joint ventures? A comparative of Japanese-Japanese and Japanese-American joint ventures in the United States. Unpublished working paper, University of Illinois at Urbana-Champaign.

Hitt, M. A., \& Barr, S. H. 1989. Managerial selection decision models: Examination of configural cue processing. Journal of Applied Psychology, 74: 53-61.

Hitt, M. A., Dacin, M. T., Tyler, B. B., \& Park, D. 1997. Understanding the differences in Korean and U.S. executives' strategic orientations. Strategic Management Journal, 18: 159-167.

Hitt, M. A., \& Middlemist, R. D. 1979. A methodology to develop the criteria and criteria weightings for assessing subunit effectiveness in organizations. Academy of Management Journal, 22: 356-374.

Hitt, M. A., Nixon, R. D., Clifford, P. G., \& Coyne, K. P. 1999. The development and use of strategic re- sources. In M. A. Hitt, P. G. Clifford, R. D. Nixon, \& K. P. Coyne (Eds.), Dynamic strategic resources: Development, diffusion and integration: 1-14. Chichestershire, England: Wiley.

Hitt, M. A., \& Tyler, B. B. 1991. Strategic decision models: Integrating different perspectives. Strategic Management Journal, 12: 327-351.

Hitt, M. A., Tyler, B. B., Hardee, C., \& Park. D. 1995. Understanding strategic intent in the global marketplace. Academy of Management Executive, 9(2): 12-19.

Hofmann, D. A. 1997. An overview of the logic and the rationale of hierarchical linear models. Journal of Management, 23: 783-804.

Inkpen, A. C., \& Beamish, P. W. 1997. Knowledge, bargaining power, and the instability of international joint ventures. Academy of Management Review, 22: $177-202$.

Jarillo, J. C. 1988. On strategic networks. Strategic Management Journal, 9: 31-41.

Jensen, M. C. 1993. The modern industrial revolution, exit and the failure of internal control systems. Journal of Finance, 48: 831-880.

Johnson, J. L., Cullen, J. B., Sakano, T., \& Takenouchi, H. 1996. Setting the stage for trust and strategic integration in Japanese-U.S. cooperative alliances. Journal of International Business Studies, 27 (special issue): 981-1004.

Khanna, T., Gulati, R., \& Nohria, N. 1998. The dynamics of learning alliances: Competition, cooperation and relative scope. Strategic Management Journal, 19: 193-210.

Klich, J. 1998. The concept of mass privatization in Poland. Theoretical and practical considerations. In D. S. Iatridis, \& J. C. Hopps (Eds.), Privatization in Central and Eastern Europe: Perspectives and approaches: 85-95. Westport, CT: Praeger.

Kogut, B., \& Zander, U. 1992. Knowledge of the firm, combinative capabilities, and the replication of technology. Organization Science, 3: 383-397.

Koh, J., \& Venkatraman, N. 1991. Joint venture formations and stock market reactions: An assessment in the information technology sector. Academy of Management Journal, 34: 869-892.

Koot, W. T. M. 1988. Underlying dilemmas in the management of international joint ventures. In. F. Contractor \& P. Lorange (Eds.), Cooperative strategies in international business: $347-367$. Lexington, MA: Lexington Books.

Lane, H. W., \& Beamish, P. W. 1990. Cross-cultural cooperative behavior in joint ventures in LDCs. Management International Review, 30(special issue): 87-102.

Lane, P. J., \& Lubatkin, M. 1998. Relative absorptive capacity and interorganizational learning. Strategic Management Journal, 19: 461-478. 
Lau, C-M. 1998. Strategic orientations of chief executives in state-owned enterprises in transition. In M. A. Hitt, J. E. Ricart i Costa, \& R. D. Nixon (Eds.), Managing strategically in an interconnected world: 101-117. London: Wiley.

Lecraw, D. J. 1984. Bargaining power, ownership, and profitability of transnational corporations in developing countries. Journal of International Business Studies, 15(2): 27-43.

Lee, C., \& Beamish, P. W. 1995. The characteristics and performance of Korean joint ventures in LDCS. Journal of International Business Studies, 26: 637-654.

Lewin, A. Y., Long, C., \& Carroll, T. 1998. The coevolution of new organization forms. Working paper, Center for International Business Education and Research, Duke University, Durham, NC.

Luthans, F., Patrick, R. R., \& Luthans, B. C. 1995. Doing business in Central and Eastern Europe: Political, economic, and cultural diversity. Business Horizons, 37(September-October): 9-16.

Lyles, M. A., \& Baird, I. S. 1994. Performance of international joint ventures in two Eastern European countries: A case of Hungary and Poland. Management International Review, 34: 313-329.

Madhok, A., \& Tallman, S. D. 1998. Resources, transactions and risks: Managing value through interfirm collaborative relationships, Organization Science, 9: $326-339$.

March, J. G., \& Levitt, B. 1999. Organizational learning. In J. G. March (Ed.), The pursuit of organizational intelligence: 75-99. Oxford, England: Blackwell.

McConnell, J. J., \& Nantell, T. J. 1985. Corporate combinations and common stock returns: The case of joint ventures. Journal of Finance, 40: 519-536.

McDonald, K. R. 1993. Why privatization is not enough. Harvard Business Review, 71(3): 49-59.

McGahan, A. M., \& Porter, M. E. 1997. How much does industry matter, really? Strategic Management Journal, 18(special issue): 15-30.

Mothe, C., \& Quelin, B. V. 1998. How firms can benefit from collaborating within R\&D consortia. In M. A. Hitt, J. E. Ricart i Costa, \& R. D. Nixon (Eds.), Managing strategically in an interconnected world: 321-347. London: Wiley.

Mowery, D. C., Oxley, J. E., \& Silverman, B. S. 1996. Strategic alliances and interfirm knowledge transfer. Strategic Management Joumal, 17(special issue): 77-92.

Nayyar, P. 1993. Performance effects of information asymmetry and economies of scope in diversified service firms. Academy of Management Journal, 36: $28-59$.

Nicolescu, O. 1998. Privatization in Romania: Present state and perspectives. In D. S. Iatridis \& J. C. Hopps (Eds.), Privatization in Central and Eastern Europe: Perspectives and approaches: 96-103. Westport, CT: Praeger.
North, D. C. 1990. Institutions, institutional change and economic performance. Cambridge, England: Cambridge University Press.

Osborn, R. N., \& Hagedoorn, J. 1997. The institutionalization and evolutionary dynamics of interorganizational alliances and networks. Academy of Management Journal, 40: 261-278.

Park, S. H., \& Russo, M. V. 1996. When competition eclipses cooperation: An event history analysis of joint venture failure. Management Science, 42: 875-890.

Parkhe, A. 1991. Interfirm diversity, organizational learning and longevity in global strategic alliances. Journal of International Business Studies, 22: 579-601.

Pedersen, T., \& Thomsen, S. 1997. European patterns of corporate ownership: A 12-country study. Journal of International Business Studies, 28: 759-778.

Sarkar, M. B., Aulakh, P. S., \& Cavusgil, S. T. 1998. The strategic role of relational bonding in interorganizational collaborations: An empirical study of the global construction industry. Journal of International Management, 4: 85-107.

Saxton, T. 1997. The effects of partner and the relationship characteristics on alliance outcomes. Academy of Management Journal, 40: 443-461.

Schilling, M. A. 1998. Technological lock-out: An integrative model of the economic and strategic factors driving technology success and failure. Academy of Management Review, 23: 267-284.

Shama, A. 1993. Management under fire: The transformation of managers in the Soviet Union and Eastern Europe. Academy of Management Executive, 7(1): $22-25$.

Shan, W., \& Hamilton, W. 1991. Country-specific advantage and international cooperation. Strategic Management Journal, 12: 419-432.

Sherman, W. S., \& Hitt, M. A. 1996. Creating corporate value: Integrating quality and innovation programs. In D. B. Fedor \& S. Ghosh (Eds.), Advances in the management of organizational quality: $219-242$. Greenwich, CT: JAI Press.

Slovic, P., \& Lichtenstein, S. 1971. Comparison of Bayesian and regression approaches to the study of information processing in judgment. Organizational Behavior and Human Performance, 6: 649-744.

Stoever, W. A. 1996. Multinationals as transferers of management skills to Poland. International Journal of Commerce \& Management, 6(1-2): 5-20.

Stumpf, S. A., \& London, M. 1981. Capturing rater policies in evaluating candidates for promotion. Academy of Management Journal, 24: 752-766.

Svetlicic, M., \& Rojec, M. 1994. Foreign direct investment and the transformation of Central European economies. Management International Review, 34: 293312.

Szyliowicz, D., Dacin, M. T., \& Ventresca, M. J. 1999. 
Political and institutional embeddedness: Alliance dynamics in the global exchange services industry. Working paper, Texas A\&M University, College Station.

Tyler, B. B., \& Steensma, H. K. 1998. The effects of executives' experiences and perception on their assessment of potential technological alliances. Strategic Management Journal, 19: 939-965.

Walker, G., \& Poppo, L. 1991. Profit centers, singlesource suppliers and transactions costs. Administrative Science Quarterly, 36: 66-87.

Michael A. Hitt (Ph.D., University of Colorado) is a Distinguished Professor of Management and holds the Paul M. and Rosalie Robertson Chair in Business Administration at Texas A\&M University. His research interests focus on international strategic alliances, innovation, corporate governance, and the importance of human capital in the new competitive landscape.

M. Tina Dacin is an associate professor at the Mays College and Graduate School of Business, Texas A\&M University. She received her Ph.D. from the University of Toronto. Her current research interests include examination of partner selection processes as well as the institutional embeddedness of strategic alliances and networks.

Edward Levitas (Ph.D., Texas A\&M University) is an assistant professor at the University of WisconsinMilwaukee. His current research interests include knowledge creation and diffusion, management of innovation, and corporate governance.

Jean-Luc Arregle is a professor in the Department of Strategy at the EDHEC Graduate School of Management. He received his $\mathrm{Ph.D}$. in strategic management from the Institut d'Administration des Entreprises (University of Aix-enProvence). His research interests are the resource-based view, brand equity, and international joint ventures.

Anca Borza is a professor of management at the Faculty of Economic Sciences, University of Babes-Bolyai, ClujNapoca, Romania. Her research interests focus on strategic management decisions facing new small business ventures, international strategic alliances, and human resources as a source of competitive advantage. 